arily brief but always studious and authoritative, a valuable source long after their publication. They were not simply valuable texts, they were always thoughtful and realistic with recommendations that were modest and practical, rather than necessarily radical or controversial. Their influence will continue well into the future.

This unique achievement is a tribute to Mrs Short's energy and personality and to her evolving position as the matriarch of a disparate group of MPs of many colours, all of whom, together with a succession of expert advisers who served the Committee over many years, held her in enormously loyal affection. I was in a position to observe this at first hand when I accompanied the Committee, under her leadership, on a tour to Sweden and Holland, an experience which I shall long remember and which closely resembled a school trip of high-spirited boys freed for a time from classes, firmly led by their benevolent and highly good humoured headmistress. On Wednesday afternoons in the House of Commons she and her Committee never shrank from probing those, including Ministers, who were suspected of economy in revealing important information.

On her retirement she found it painful to be separated from her Committee and all the inquiries which she would still wish to initiate and pursue. She was honoured at a gathering of all those who had been members of the Committee or its advisers during the many years she had been in the chair, including the presence of $\mathrm{Mr}$ Speaker. Now she has undertaken a new challenge as a Member of the Medical Research Council and is busily taking on other new commitments.

There is no doubt, however, that her reports and influence have made an enduring mark upon the future development and direction of health care, psychiatry and medico-politics.

Mr President, for her distinguished service over many years, it is my privilege to present to you for the Award of Honorary Fellowship of the Royal College of Psychiatrists, Mrs Renée Short.

\title{
Section for the Psychiatry of Mental Handicap
}

\section{Guidelines for Regional Representatives}

\section{Roles and duties}

Regional Representatives are internal College appointments to assist Regional Advisers and the Chairman of the Section in a variety of matters. The official representatives of the College at Regional level are Regional Advisers.

Regional Advisers are expected to consult Regional Representatives on the following matters:

job descriptions for senior registrar posts and consultant posts in mental handicap;

nominations to serve on Appointments Committees for senior registrars in England and Wales;

other aspects of services and the implementations of College policy.

Officers of the Section for the Psychiatry of Mental Handicap may consult Regional Representatives on the following matters:

nominations for distinction awards;

nominations for Fellowship;

other aspects of services and implementation of College policy.
Regional Representatives are expected to alert/ consult with the Chairman on any local issues of potentially national importance in relation to services for the mentally handicapped.

\section{Useful reference documents}

Royal College of Psychiatrists (1983) Mental handicap services - the future. Bulletin of the Royal College of Psychiatrists, 7, 131-134.

-(1985) Registrar training in mental handicap. Bulletin of the Royal College of Psychiatrists, 9, 206.

-(1985) Guidelines for regional advisers on consultant psychiatrist posts in mental handicap. Bulletin of the Royal. College of Psychiatrists, 9, 207-208.

-(1986) Psychiatric services for mentally handicapped adults and young people. Bulletin of the Royal College of Psychiatrists, 10, 321322. 
- (1986) Undergraduate training in mental handicap. Bulletin of the Royal College of Psychiatrists, 10, 292.

-(1986) Interim guidelines on consent to medical and surgical treatment, contraception, fertilisation and abortion in the mentally handicapped. Bulletin of the Royal College of Psychiatrists, 10, 184-185.

-(1987) Mental handicap nurses - training in psychiatric aspects of care. Bulletin of the Royal College of Psychiatrists, 11, 355-356.

-(1988) Psychiatric services for the mentally handicapped. Bulletin of the Royal College of Psychiatrists, 12, 155.

JOINT COMMITTEe ON Higher Psychiatric TRAINING (1987) Requirements for specialist training in mental handicap psychiatry. Handbook (1987 edition) 39-42.

\section{Current key issues}

Medical staffing in mental handicap.

Services for the psychiatrically and behaviourally disturbed mentally handicapped and offenders.

Training opportunities in mental handicap at registrar and senior registrar level.

\section{Section office bearers}

Chairman: Dr Diana Dickens, Rampton Hospital, Retford, Notts, DN22 (telephone: 077 784321 extension 200)

Secretary: Dr David Wilson, Dept of Mental Handicap, Floor E, South Block, University Hospital, Queens Medical Centre, Nottingham NG7 2UH (telephone: 0602 421421 )

\section{The 25th anniversary of the British Journal of Psychiatry}

To mark the occasion of the 25th anniversary of the British Journal of Psychiatry, Professor Hugh Freeman, the Editor, hosted a buffet in the Council Room at the College on 5 October 1988. Incidentally, the event also marked the 135th anniversary of the Asylum Journal and the 133rd anniversary of the Journal of Mental Science.

Guests included two of Professor Freeman's predecessors: Dr Edward Hare (editor 1973-1977) and Dr John Crammer (editor 1977-1983) and past and present Officers of the College, as well as a large number of the Editorial Committee, Journal assessors, and Journal staff, past and present.

Professor Freeman thanked all those connected with the Journal for contributing to its continuing success both at home and on the international scene.

The Journal's high reputation provides the College with a range of benefits which it is hoped will increase along with future developments.

\section{Caring for a community}

The College has recently published a series of briefing papers entitled 'Caring for a Community' which summarises the College's opinion and advice on the current developments and changes in psychiatric care in hospital and the community. Copies of this pack are available from the College for $£ 2.50$.

\section{Christmas holiday}

The College will be closed from 7.00 p.m. on Friday, 23 December 1988 until 8.00 a.m. on Tuesday, 3 January 1989. 